\title{
Water distribution model for center pivot end gun sprinklers
}

\author{
Giuliani Prado ${ }^{1}$, Alberto Colombo ${ }^{2}$ \& Antônio C. Barreto ${ }^{3}$ \\ ${ }^{1}$ Universidade Estadual de Maringá/Departamento de Engenharia Agrícola, Cidade Gaúcha, PR, Brasil. E-mail: gprado@uem.br (Corresponding author) \\ - ORCID: 0000-0001-5442-7446 \\ ${ }^{2}$ Universidade Federal de Lavras/Departamento de Engenharia, Lavras, MG, Brasil. E-mail: acolombo@deg.ufla.br - ORCID: 0000-0002-7872-9796 \\ ${ }^{3}$ Instituto Federal de Educação, Ciência e Tecnologia do Triângulo Mineiro. Uberaba, MG, Brasil. E-mail: barreto@iftm.edu.br - ORCID: 0000-0002- \\ $1638-8375$
}

\begin{abstract}
End gun sprinklers can increase the irrigated area by center pivot irrigation systems without a substantial investment. This study was carried out at the Universidade Federal de Lavras, MG state, Brazil, and aimed to describe and validate a water distribution model for center pivot end gun sprinklers. The gun sprinkler PLONA-RL250 ${ }^{\oplus}$, attached at the end point of a center pivot, was used to evaluate the model in field tests. The sprinkler working conditions considered were nozzle diameters of 14 x $6 \mathrm{~mm}$, working pressure of $292 \mathrm{kPa}$, and four asymmetric wetted angle adjustments $\left(95+20^{\circ} ; 90+90^{\circ} ; 60+60^{\circ} ; 45+45^{\circ}\right)$. These tests were carried out for wind speed lower than $0.9 \mathrm{~m} \mathrm{~s}^{-1}$. The measured and simulated irrigation depths showed an average absolute difference of $0.65 \mathrm{~mm}$ and determination coefficients from 71.55 to $89.37 \%$. Based on the confidence coefficient $(c=0.82)$ the model can be classified as very good $(0.76 \leq c \leq 0.85)$. Sprinkler wetted angle adjustment of $110^{\circ}\left(95+20^{\circ}\right)$ resulted in uniform water distribution and, for effective radius of throw between 70 to $90 \%$ of the gun sprinkler's radius of throw, this working condition resulted in Christiansen's uniformity greater than $80 \%$.
\end{abstract}

Key words: nozzle diameter, wetted angle, working pressure

\section{Modelo de distribuição de água para canhões finais em pivô central}

RESUMO: Canhões finais podem aumentar a área irrigada por sistemas de irrigação tipo pivô central sem um investimento substancial. Este estudo foi desenvolvido na Universidade Federal de Lavras, MG, Brasil, e objetivou descrever e validar um modelo de distribuição de água de canhão hidráulico em extremidade final de pivô central. O canhão hidráulico PLONA-RL250 ${ }^{\circ}$, acoplado na extremidade final de um pivô central, foi usado para avaliar o modelo nos testes de campo. As condições de trabalho do aspersor consideradas foram diâmetro de bocais de 14 x $6 \mathrm{~mm}$, na pressão de $292 \mathrm{kPa}$, e quatro ângulos de giro assimétricos $\left(95+20^{\circ} ; 90\right.$ $+90^{\circ} ; 60+60^{\circ} ; 45+45^{\circ}$ ). Esses ensaios foram conduzidos para velocidades de vento inferiores a $0,9 \mathrm{~m} \mathrm{~s}^{-1}$. As lâminas mensuradas e simuladas apresentaram uma diferença absoluta média de $0,65 \mathrm{~mm}$ e coeficientes de determinação entre 71,55 e $89,37 \%$. O índice de confiança obtido $(c=0,82)$ classificou o modelo como muito bom $(0,76 \leq c \leq 0,85)$. O ajuste do ângulo de giro do aspersor de $110^{\circ}\left(95+20^{\circ}\right)$ promoveu distribuição uniforme de água e para raio efetivamente irrigado entre 70 a $90 \%$ do raio de alcance do canhão hidráulico, essa condição operacional resultou em coeficientes de uniformidade de Christiansen maiores que $80 \%$.

Palavras-chave: diâmetro do bocal, ângulo de giro, pressão de serviço 


\section{INTRODUCTION}

The use of a gun sprinkler attached at the end point of a center pivot allows adding irrigation area without a substantial investment (Waller \& Yitayew, 2016). In plantation areas which have square geometric shapes, the corners represent about $21.5 \%$ of the area not irrigated by a center pivot (Bernuth, 1983; Frizzone et al., 2011).

According to Prado \& Colombo (2005) and Li et al. (2016, 2017), the lack of information on end gun working conditions, mainly regarding the combinations of nozzle diameters, working pressure, and wetted angle, have led to a non-uniform water application. Moreover, simulations can be a relevant tool for decision making in irrigation projects and management to improve water distribution (Zolin et al., 2012).

Solomon \& Kodoma (1978) employed distribution curves of a gun sprinkler to simulate the water distribution of a center pivot end gun for different wetted angles. In these simulations the assumption of a gun sprinkler moving in a straight line was considered (Bittinger \& Longenbaugh, 1962). However, simulations considering the end gun sprinkler in a circular motion provide more accurate water application data.

Recommendations of wetted angle for end gun sprinklers, based on Solomon \& Kodoma (1978) and given by Rolland (1982), present water application patterns for three different adjustments of the end gun wetted angle $\left(180,150\right.$ and $\left.90^{\circ}\right)$. In accordance with these suggestions, an end gun wetted angle of $150^{\circ}$, asymmetric to the center pivot lateral line $(105+$ $45^{\circ}$ ), provides suitable water distribution pattern.

Intending to aid in the selection of gun sprinklers attached at the end point of center pivots, this paper aimed to: i) develop a mathematical model to simulate water distribution of a center pivot end gun moving in a circular motion; ii) validate the mathematical model, comparing the digital simulated values with in-field test values.

\section{Material and Methods}

A mathematical model was developed at the Universidade Federal de Lavras (UFLA), Lavras, MG state, Brazil. To validate this model, the in-field tests were performed at the Instituto Federal de Educação, Ciência e Tecnologia do Triângulo Mineiro (IFTM), in Uberaba, MG state, Brazil.

The simulation of water distribution for center pivot end gun sprinklers (Figure 1) considered a center pivot lateral length (Ll) and two wetted sectors from an imaginary line which defines the center pivot lateral: i) Sector I, located above this line $\left(\theta_{1}\right)$ and; ii) Sector II, located below this line $\left(\theta_{2}\right)$. Thus, the gun sprinkler wetted sector angle was obtained by $\theta_{1}+\theta_{2}$.

A straight radial row of water collectors (Figure 1), which has the fixed pivot point as reference, is used to simulate the water distribution applied by the end gun. Hence, the total number of collectors $(\mathrm{Nt}=\mathrm{Nb}+\mathrm{Nf})$ required, Eqs. 1, 2 and 3, covering the gun sprinkler wetted radius and located backward and forward from the sprinkler, can be computed by:

$\mathrm{Nb}=\left\{\begin{array}{l}\mathrm{Nb} \leftarrow 0 \text { if } \theta_{\mathrm{j}} \leq \frac{\pi}{2} \\ \mathrm{Nb} \leftarrow \operatorname{trunc}\left\{\frac{\sin \left[\max \left(\theta_{\mathrm{j}}\right)-\frac{\pi}{2}\right] \mathrm{R}}{\Delta \mathrm{e}}+1.5\right\} \text { if } \theta_{1}>\frac{\pi}{2} \text { or } \theta_{2}>\frac{\pi}{2} \\ \mathrm{j}=1 \text { to } 2\end{array}\right.$

$$
\mathrm{Nf}=\operatorname{trunc}\left(\frac{\mathrm{R}}{\Delta \mathrm{e}}+1.5\right)
$$

$$
\mathrm{Nt}=\mathrm{Nb}+\mathrm{Nf}
$$

where:

$\mathrm{Nt}$ - total number of collectors;

$\mathrm{Nb}$ and $\mathrm{Nf}$ - number of collectors backward and forward, respectively, from the center pivot endpoint;

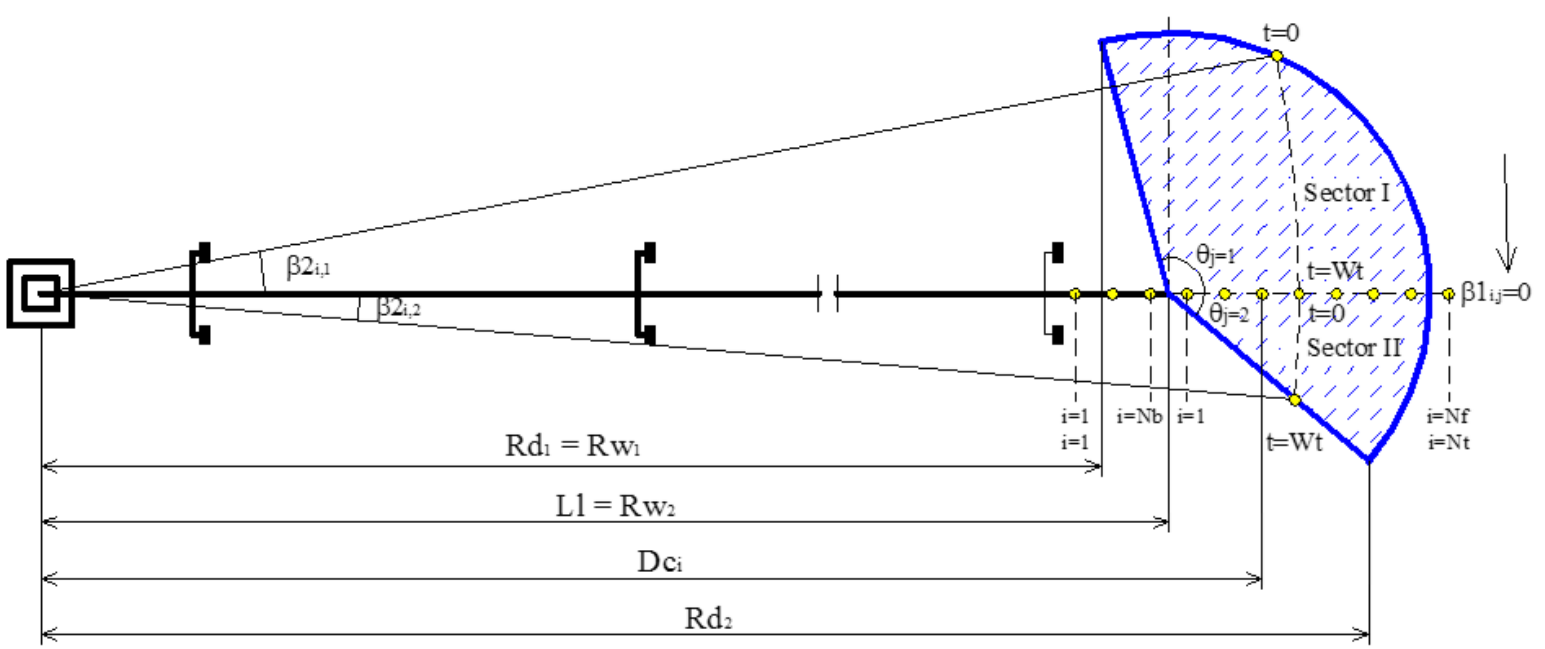

$\mathrm{t}$ - water application time; Wt - sprinkler wetting time; $\mathrm{Nt}$ - total number of collectors; $\mathrm{Nb}$ and $\mathrm{Nf}$ - number of collectors backw ard and forward, respectively, from the center piv ot endpoint, $\theta_{\mathrm{j}}=1$ and $\theta_{\mathrm{j}}=2$ - sprinkler wetted angles, respectively, for sector I and II; $\beta 1_{i, j}$ and $\beta 2_{i, j}$ - angles set between the starting and the finishing time of water application in a collector $i$, respectively, for the sector I $(j=1)$ and II $(j=2) ; \mathrm{L} 1$ - center pivot lateral length; Dci - distance of a collector $\mathrm{i}$ to the piv ot point; Rdj - radial distance to the fixed pivot point for the sector $I(j=1)$ and $I I(j=2)$ and $R w j$ - the nearest radial distance from the wetted gun sprinkler circle to the fixed pivot point for the sector $\mathrm{I}(\mathrm{j}=1)$ and $\mathrm{II}(\mathrm{j}=2)$

Figure 1. Water collectors considered in the water distribution simulation of a gun sprinkler set up at the end point of a center pivot 
$\Delta \mathrm{e} \quad$ - collector spacing, $\mathrm{m}$;

$\max (\delta)$ - mathematical function which return the maximum value of $\delta$;

$\mathrm{R}$ - gun sprinkler's radius of throw, $\mathrm{m}$; and,

$\operatorname{trunc}(\delta)$ - mathematical function which returns the integer part of $\delta$.

The radial distance (Dc), Eq. 4, from each water collector to the pivot point, can be calculated by the subscribed value "i" by:

$$
\mathrm{Dc}_{\mathrm{i}}=\mathrm{L} 1+(\mathrm{i}-\mathrm{Nb}-0.5) \Delta \mathrm{e} \quad 1 \leq \mathrm{i} \leq \mathrm{Nt}
$$

where:

Dc - distance of a catch can to the pivot point, m; and,

Ll - center pivot lateral length, $\mathrm{m}$.

During the end gun sprinkler motion, to set the water collector position, it is necessary to determine the edge distances (Figure 1) of the wetted circle angle to the fixed pivot point by Eq. 5:

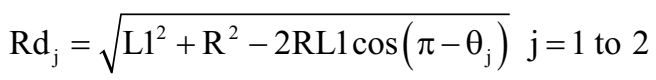

where:

$\mathrm{Rd}_{\mathrm{j}}$ - radial distance to the fixed pivot point, $\mathrm{m}$; and,

$\theta_{j} \quad$ - wetter angle adjustment for the sectors $I(j=1)$ and II $(j=2)$, rad.

Projecting a perpendicular line, from the pipe lateral toward the edge wetted gun sprinkler circle (Figure 1), sets the nearest radial distance to the fixed pivot point, Eq. 6, calculated as:

$$
\mathrm{Rw}_{\mathrm{j}}=\left\{\begin{array}{l}
\mathrm{Rw}_{\mathrm{j}} \leftarrow \mathrm{L} 1+\cos \left(\theta_{\mathrm{j}}\right) \mathrm{R} \text { if } \theta_{\mathrm{j}}>\frac{\pi}{2} \\
\mathrm{Rw}_{\mathrm{j}} \leftarrow \mathrm{L} 1 \text { if } \theta_{\mathrm{j}} \leq \frac{\pi}{2} \\
\mathrm{j}=1 \text { to } 2
\end{array}\right.
$$

where:

$\mathrm{Rw}_{\mathrm{j}}$ - the nearest radial distance from the wetted gun sprinkler circle to the fixed pivot point, $\mathrm{m}$.

The relative position of each water collector from the end gun sprinkler, when the water application time starts $(\mathrm{t}=0)$ and finishes $(t=W t)$, is depicted in Figure 1. Within this time interval, it is possible to set the angles $\beta 1$ (Eq. 7) and $\beta 2$ (Eq. 8 ), which are computed by the equations:

$$
\beta 1_{i, j}=\left\{\begin{array}{l}
\beta 1 \leftarrow 0 \\
\beta 1 \leftarrow \theta_{j}+a \sin \left[\frac{\mathrm{Ll} \sin \left(\theta_{\mathrm{j}}\right)}{\mathrm{Dc}}\right]-\pi \text { if } \frac{\pi}{2}<\theta_{\mathrm{j}}<\pi \text { and } \frac{\mathrm{Ll} \sin \left(\theta_{\mathrm{j}}\right)}{\mathrm{Dc} c_{\mathrm{i}}}<1 \\
\beta 1 \leftarrow 0 \text { if } \beta 1<0 \text { or } \sin \left(\theta_{\mathrm{j}}\right)<\frac{\mathrm{Dc} \mathrm{c}_{\mathrm{i}} \sin (\beta 1)}{\mathrm{R}} \\
\mathrm{j}=1 \text { to } 2 \quad 1 \leq \mathrm{i} \leq \mathrm{Nt}
\end{array}\right.
$$

$$
\beta 2_{i, j}=\left\{\begin{array}{l}
\beta 2 \leftarrow 0 \\
\beta 2 \leftarrow \theta_{j}-a \sin \left[\frac{L 1 \sin \left(\theta_{j}\right)}{D c_{i}}\right] \quad \text { if } \quad \mathrm{Rw}_{\mathrm{j}} \leq \mathrm{Dc}_{\mathrm{i}}<\mathrm{Rd}_{\mathrm{j}} \text { and } \frac{\mathrm{Ll} \sin \left(\theta_{\mathrm{j}}\right)}{\mathrm{Dc} c_{\mathrm{i}}}<1 \\
\beta 2 \leftarrow \mathrm{a} \cos \left[\frac{\mathrm{Ll^{2 } + D c _ { \mathrm { i } } ^ { 2 } - \mathrm { R } ^ { 2 }}}{2 \mathrm{LlDc} c_{\mathrm{i}}}\right] \quad \text { if } \mathrm{Rd}_{\mathrm{j}} \leq \mathrm{Dc} \mathrm{c}_{\mathrm{i}}<\mathrm{Ll}+\mathrm{R} \\
\beta 2 \leftarrow 0 \text { if } \frac{\mathrm{Dc}_{\mathrm{i}} \sin (\beta 2)}{\mathrm{R}}>1 \\
\mathrm{j}=1 \text { to } 2 \quad 1 \leq \mathrm{i} \leq \mathrm{Nt}
\end{array}\right.
$$

where:

$\beta 1$ and $\beta 2$ - angles set between the starting and the finishing time of water application in a collector, respectively, for the wetted sector I and II, rad.

Assuming that the sprinkler wetted angle moves with a distinct tangential speed at each water collector point, the wetting time (Wt) duration, Eq. 9, for each wetted sector, can be calculated as:

$$
\mathrm{Wt}=\frac{\operatorname{Rt}\left(\beta 2_{\mathrm{i}, \mathrm{j}}-\beta 1_{\mathrm{i}, \mathrm{j}}\right)}{2 \pi}
$$

where:

Wt - sprinkler wetting time, h; and,

Rt - center pivot rotation time per revolution, h.

The irrigation depth applied, in each water collector, represents the integration sums of the application rates, during the sprinkler wetting time, for each wetted sector (Figure 1). Thus, the total water depth caught in a collector can be given by Eq. 10:

$$
\begin{aligned}
& \mathrm{D}_{\mathrm{i}}=\mathrm{D}_{\mathrm{i}, 1}+\mathrm{D}_{\mathrm{i}, 2} \\
& \mathrm{D}_{\mathrm{i}, \mathrm{j}}=\int_{0}^{\mathrm{w}_{\mathrm{t}}} \mathrm{A}[\mathrm{r}(\mathrm{t})] \mathrm{dt}=\frac{\Delta \mathrm{t}}{3}\left\{\sum_{\mathrm{k}=0}^{19}[\mathrm{~A}[\mathrm{r}(2 \mathrm{k} \Delta \mathrm{t})]+4 \mathrm{~A}[\mathrm{r}((2 \mathrm{k}+1) \Delta \mathrm{t})]+\mathrm{A}[\mathrm{r}((2 \mathrm{k}+2) \Delta \mathrm{t})]]\right\} \\
& \text { with: } \mathrm{r}(\mathrm{t})=\sqrt{\mathrm{Dc}_{\mathrm{i}}^{2}+\mathrm{Ll}^{2}-2 \mathrm{Dc}_{\mathrm{i}} \mathrm{Ll} \cos \left(\beta 1_{\mathrm{i}, j}+\frac{2 \pi}{\mathrm{Rt}} \mathrm{t}\right)} \quad \Delta \mathrm{t}=\frac{\mathrm{Wt}}{40}
\end{aligned}
$$

where:

$\mathrm{D}_{\mathrm{i}}$ - total irrigation depth applied to each water collector, identified by the subscript i, mm;

$\mathrm{D}_{\mathrm{i}, \mathrm{j}}$ - irrigation depth applied to each water collector, identified by the subscripts $i$ and $j$, with $j=1$ for the sector I and $\mathrm{j}=2$ for the sector II, $\mathrm{mm}$;

A - application rate from the water distribution curve of the sprinkler, $\mathrm{mm} \mathrm{h}^{-1}$;

$\mathrm{r}$ - radial distance to the sprinkler, $\mathrm{m}$;

$\mathrm{t}$ - water application time, h; and,

$\Delta \mathrm{t} \quad$ - subinterval of water application time, $\mathrm{h}$.

In order to evaluate the simulation data from the proposed model, at the Instituto Federal de Educação, Ciência e Tecnologia do Triângulo Mineiro (IFTM), in the city of Uberaba, MG state, Brazil, the sprinkler PLONA-RL250 ${ }^{\circ}$ was attached at the end point of a center pivot. This part circle gun sprinkler has a trajectory angle of $24^{\circ}$, a flange coupling of $2 \frac{1}{2}$ ", two impact arms and a slow reverse system.

The gun sprinkler was set up at the end point of a center pivot, located in an area with $1 \%$ of slope, which had a lateral 
length of $300.7 \mathrm{~m}$ (5 spans of $275.7 \mathrm{~m}$ and an overhang of $25 \mathrm{~m}$ ) and spray-type sprinklers. During the water distribution tests, the gun sprinkler worked with nozzle diameters of $14 \times 6 \mathrm{~mm}$ under the working pressure of $292 \mathrm{kPa}$.

The tests were performed at wind speeds less than $0.9 \mathrm{~m} \mathrm{~s}^{-1}$ and, according to Solomon \& Kodoma (1978), the sprinkler wetted angles chosen, respectively, for $\theta_{1}$ and $\theta_{2}$ were: i) $95+20^{\circ}$; ii) $90+90^{\circ}$; iii) $45+45^{\circ}$; iv) $60+60^{\circ}$. The sprinkler tangential speed was $157 \mathrm{~m} \mathrm{~h}^{-1}$ for the percentagetimer set up as $60 \%$, which has an average application depth of $4.15 \mathrm{~mm}$.

Based on the ASAE Standard S436.1 (ASAE, 1996), the water depths applied by the gun sprinkler were measured in two radial rows of water collectors set apart at an angle of $3^{\circ}$, which started at the fixed pivot point. The water collectors of $0.10 \mathrm{~m}$ diameter opening and spaced by $2 \mathrm{~m}$ from each other at the collector row were installed $3.5 \mathrm{~m}$ below the sprinkler main nozzle. In each row 30 water collectors were installed, with 5 and 25 collectors set up, respectively, backward and forward from the gun sprinkler point.

Aiming to evaluate the model accuracy, the water depths measured in the tests and simulated with the gun sprinkler PLONA-RL250 ${ }^{\circ}$, which had absolute difference greater than zero (Oliveira et al., 2013), were compared by: i) average of the absolute difference between measured and simulated values; ii) determination coefficient $\left(\mathrm{R}^{2}\right)$ and; iii) confidence coefficient (c) proposed by Camargo \& Sentelhas (1997), which is given by the product of correlation coefficient ( $r$ ) and exactness coefficient (d) (Willmott et al., 1985).

The data measured in the field tests, simulated from the sprinkler PLONA-RL250 ${ }^{\circ}$ radial profile and simulated from the theoretical radial profile with uniform shape (Christiansen's profile F - Christiansen, 1942) were used to calculate Christiansen's coefficient of uniformity (CU) (Hermann \& Hein, 1968), weighted by the radial distance from the fixed pivot point.

Keller \& Bliesner (1990) have recommended an effectively irrigated radius of throw from 75 to $80 \%$ of the gun sprinkler's radius of throw for end guns. In order to evaluate this recommendation, the $\mathrm{CU}$ values were determined for the gun sprinkler with effectively irrigated radiuses of throw (R) of $100,90,80$ and $70 \%$ of the gun sprinkler's radius of throw.

\section{RESUlts AND Discussion}

The water distribution curve of gun sprinkler PLONA$\mathrm{RL} 250^{\circ}$, for the $14 \times 6 \mathrm{~mm}$ nozzle diameters under working pressure of $292 \mathrm{kPa}$, is presented in Figure 2. This curve has a large similarity to the theoretical geometric shape of Christiansen's uniform water distribution curve (Profile F) (Christiansen, 1942).

Prado et al. (2013) pointed out that gun sprinkler distribution curves have a uniform water distribution along the sprinkler wetted radius, working under adequate conditions of nozzle diameters, working pressure, and jet angle. However, inappropriate sets of nozzle diameters and working pressure provide a doughnut pattern (Christiansen's Profile E) with a large amount of water applied at the endpoint of water distribution curve, which results in a low water application uniformity (Prado et al., 2007, 2008).

The water depth measured in the field tests from the gun sprinkler PLONA-RL250 ${ }^{\circ}$, working under four different wetted angles at the endpoint of a center pivot, as well as water depth values simulated, for the gun sprinkler distribution curve (Figure 2) and the uniform radial profile, are shown in Figure 3.

The likeness of PLONA-RL250 ${ }^{\circ}$ distribution curve and the theoretical Christiansen's profile $\mathrm{F}$ has been confirmed with the water depths simulated from these two radial profiles (Figure 3 ). The coefficients of determination between measured and simulated irrigation depth had a range of 71.55 to $89.37 \%$ for the four wetted angle conditions tested (Figures 3A, B, C and D).

Monteiro et al. (2001), comparing measured and simulated data to validate a water distribution model for solid set sprinkler irrigation, found coefficients of determination ranging from 51 to $89 \%$. According to the authors, these differences are due to slight variations in the experimental method to set the sprinkler water distribution curves and climatic conditions (wind speed and direction) to perform the field tests.

Water depths of the end gun sprinkler PLONA-RL250 ${ }^{\circ}$ on a center pivot, measured in the field test and simulated by the computer program for the four wetted angle conditions (Figures 3A, B, C and D), were related to each other (Figure 4). The measured and simulated data had an average difference of $0.65 \mathrm{~mm}$ and a coefficient of determination of 0.776 . In the validation of a water distribution model for the irrigation

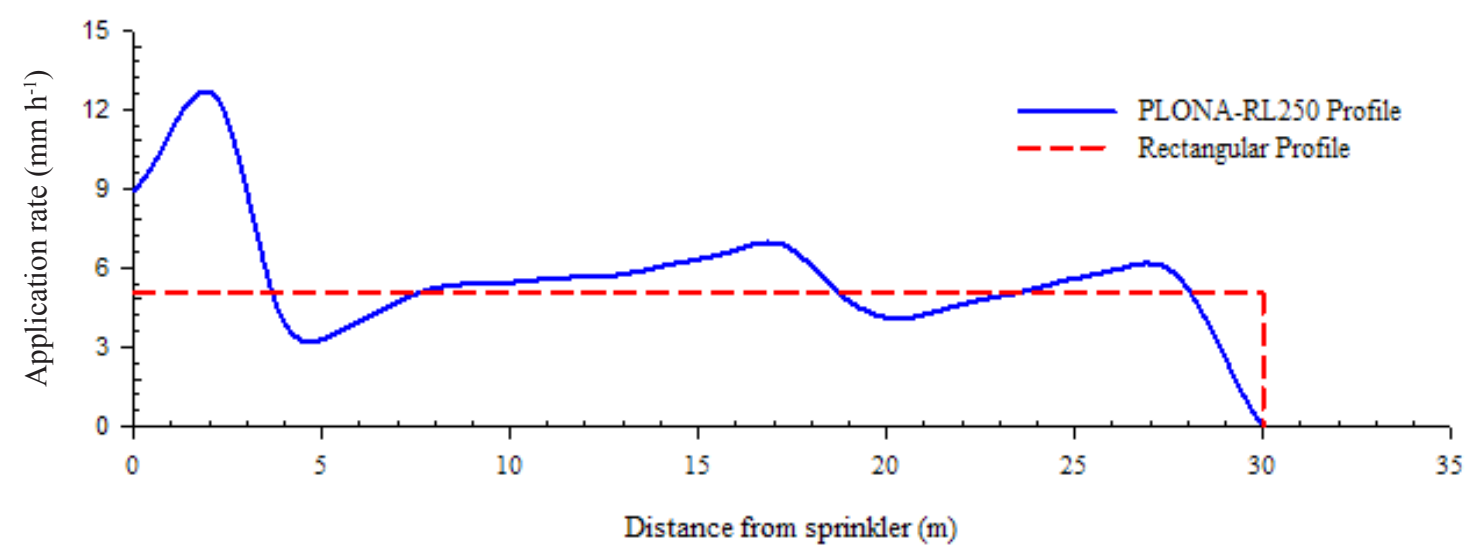

Figure 2. Water distribution curve of the gun sprinkler PLONA-RL250 ${ }^{\circledR}$ and theoretical geometric shape of Christiansen's profile F (Rectangular profile) 

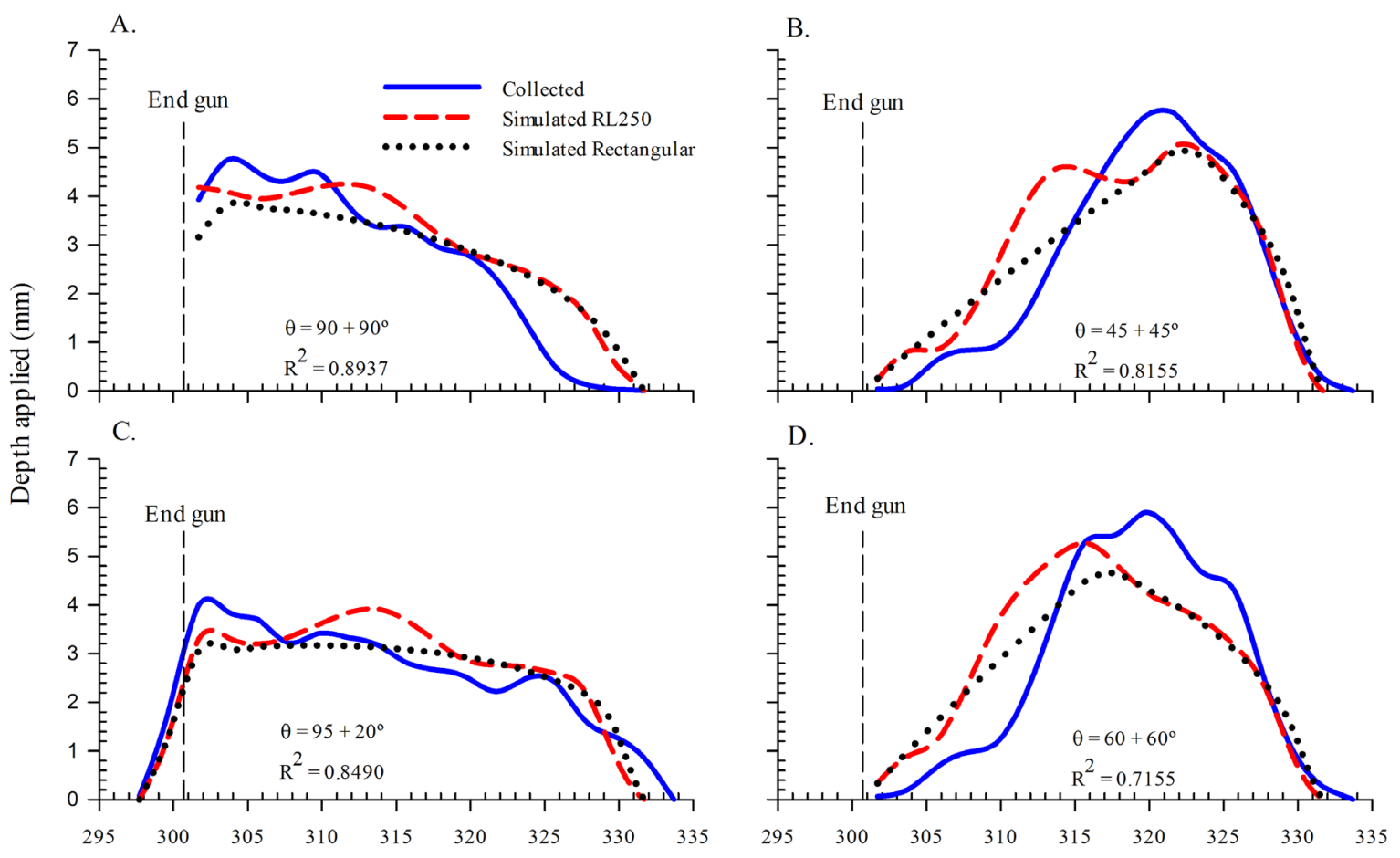

Distance from pivot point $(\mathrm{m})$

Figure 3. Water depth curves measured in the field test, simulated from the radial profile of the PLONA-RL250 ${ }^{\circledR}$ gun sprinkler and simulated from the uniform radial profile (Christiansen's profile F) for different wetted angles (A, B, C and D) of a center pivot end gun

sprinkler systems, Faria et al. (2012) found a coefficient of determination of 0.78 .

The confidence coefficient (c) was equal to 0.820 (Figure 4), which classified the simulation model as very good $(0.76 \leq \mathrm{c} \leq 0.85)$. According to Oliveira et al. (2013), in the performance evaluation of water distribution models for sprinkler irrigation, it is unreasonable to consider that the differences between measured and simulated data represent the unique limitation of the model. Minor errors in data collection and meteorological variation during the tests have also influenced these discrepancies.

The water application depths, measured in the field and simulated from the distribution curve of the gun sprinkler

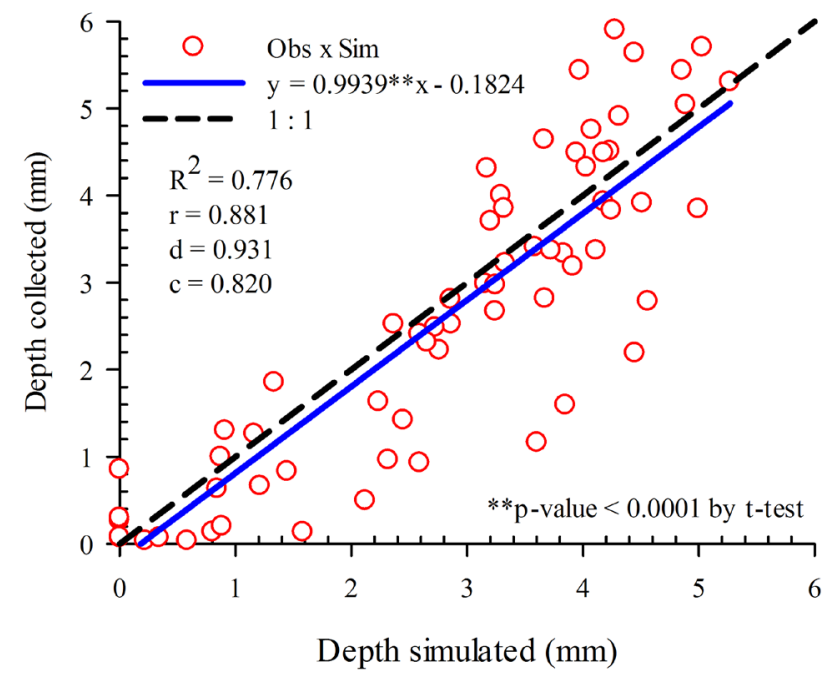

Figure 4. Relationship between the 68 measured and simulated water depths from the gun sprinkler PLONA-RL $250^{\circ}$ attached at the endpoint of a center pivot
PLONA-RL $250^{\circ}$ and from the uniform theoretical radial profile, for four different sprinkler wetted angle adjustments (Figures 3A, B, C and D), were used to compute Christiansen's coefficient of uniformity (CU) for four distinct effectively irrigated radiuses of throw $(100,90,80$ and $70 \%$ of the gun sprinkler's radius of throw) (Figure 5). There was a trend towards overestimation of the $\mathrm{CU}$ values determined by the simulation model.

Comparing the CU data, measured in field tests and set by mathematical models for solid set sprinkler systems, Faria et al. (2012) observed an underestimation of the simulated data. However, Li et al. (2015) noticed that the CU data were underestimated or overestimated, depending on the working condition set to the irrigation system.

The sprinkler wetted angle of $180^{\circ}\left(90+90^{\circ}\right)$ (Figure $3 \mathrm{~A}$ ) and $115^{\circ}\left(95+20^{\circ}\right)$ (Figure $3 \mathrm{C}$ ) provided steadier water application depths along the sprinkler radius of throw; as a result, the $\mathrm{CU}$ data reached high values (Figures 5A and C). Based on Rolland (1982), Keller \& Bliesner (1990) and Colombo (2003), a gun sprinkler attached to the endpoint of center pivot irrigation systems leads to a uniform water distribution for asymmetric wetted angle adjustments of about $150^{\circ}\left(105+45^{\circ}\right)$.

Regarding water application depths achieved for the gun sprinkler wetted angles of $90^{\circ}\left(45+45^{\circ}\right)$ (Figure $3 \mathrm{~B}$ ) and $120^{\circ}$ $\left(60+60^{\circ}\right)($ Figure $3 \mathrm{D})$, the water application time in each water collector is rather different. These wetted angle adjustments result in low CU values (Figures 5B and D) and they should not be employed.

The wetted angle adjustment of $115^{\circ}\left(95+20^{\circ}\right)$, for effectively irrigated radius less than $90 \%$ of the gun sprinkler's 
A

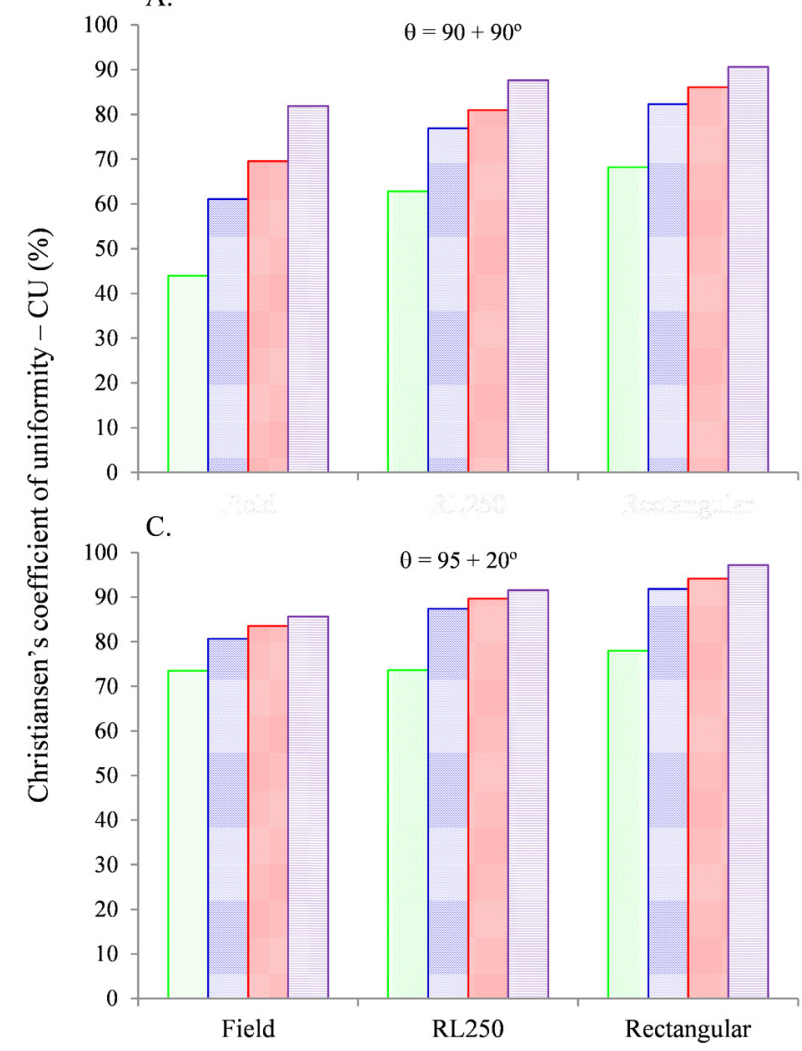

B.

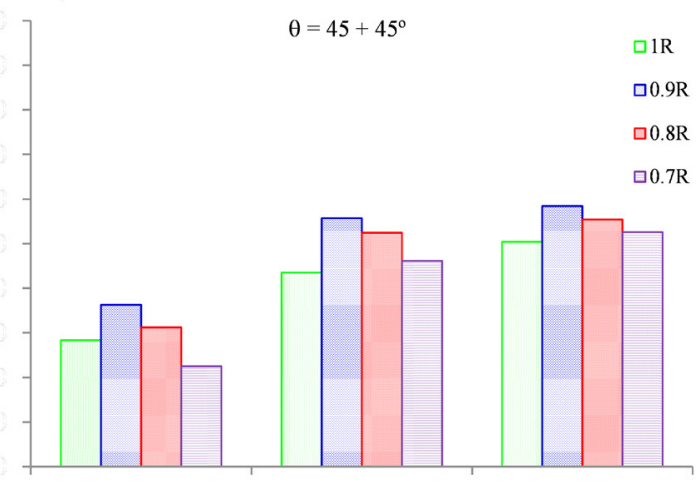

D.

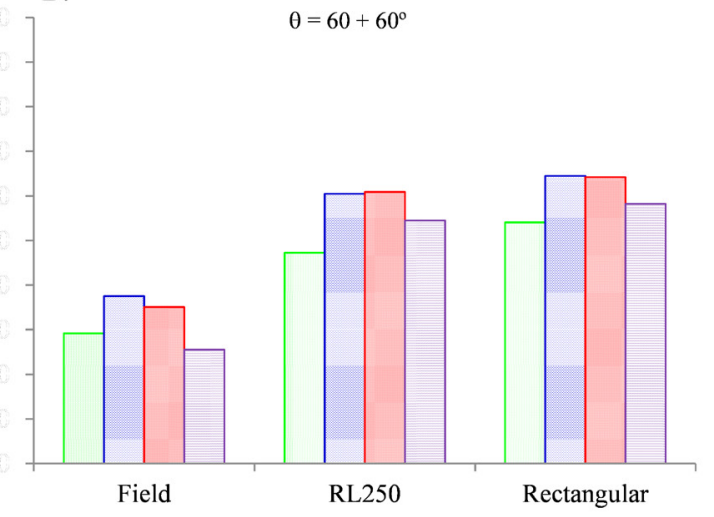

Figure 5. Christiansen's coefficient of uniformity computed from water depths measured in field test and simulated from the end gun sprinkler PLONA-RL250 ${ }^{\circ}$ for the different wetted angles (A, B, C and D) and effectively irrigated radiuses of throw $(100,90,80$ and $70 \%$ of the gun sprinkler's radius of throw)

radius of throw, showed CU values greater than $80 \%$ (Figure 5C). Keller \& Bliesner (1990) have recommended an effectively irrigated radius of throw of $75 \%$ of the gun sprinkler's radius of throw working at the endpoint of a center pivot.

\section{Conclusions}

1. The developed model can be employed to simulate the water distribution of any end gun sprinkler, as long as the sprinkler water distribution curve is known.

2. Although the model was developed for no-wind conditions, wind speeds less than $0.9 \mathrm{~m} \mathrm{~s}^{-1}$, measured and simulated water application depths showed minor differences.

\section{Literature Cited}

ASAE - American Society of Agricultural Engineers. Standard 436.1: Test procedure for determining the uniformity of water distribution of center pivot and lateral move irrigation machines equipped with spray or sprinkler nozzles. St. Joseph: ASAE, 1996. 8p.

Bernuth, R. D. von. Nozzling considerations for center pivots with end guns. Transactions of the American Society of Agricultural Engineers, v.26, p.419-422, 1983. https://doi. org/10.13031/2013.33950

Bittinger, M. W.; Longengauch, R. A. Theoretical distribution of water from a moving irrigation sprinkler. Transactions of the American Society of Agricultural Engineers, v.5, p.26-30, 1962. https://doi. org/10.13031/2013.40926
Camargo, A. P.; Sentelhas, P. C. Avaliação do desempenho de diferentes métodos de estimativa da evapotranspiração potencial no Estado de São Paulo, Brasil. Revista Brasileira de Agrometeorologia, v.5, p.89-97, 1997.

Christiansen, J. E. Irrigation by sprinkling. Berkeley: California Agricultural Station, 1942. 124p. Bulletin, 670

Colombo, A. Pivô central. In: Miranda, J. H.; Pires, R. C. M. (eds.). Irrigação. Jaboticabal: Sociedade Brasileira de Engenharia Agrícola, 2003. Cap.11, p.209-258.

Faria, L. C.; Beskow, S.; Colombo, A.; Oliveira, H. F. E. de. Modelagem dos efeitos do vento na uniformidade da irrigação por aspersão: Aspersores de tamanho médio. Revista Brasileira de Engenharia Agrícola e Ambiental, v.16, p.133-141, 2012. https://doi. org/10.1590/S1415-43662012000200002

Frizzone, J. A.; Rezende, R.; Freitas, P. S. L. Irrigação por aspersão. Maringá: EDUEM, 2011. 271p.

Hermann, D. F.; Hein, P. R. Performance characteristics of selfpropelled center-pivot sprinkler irrigation system. Transactions of the American Society of Agricultural Engineers, v.2, p.11-15, 1968. https://doi.org/10.13031/2013.39320

Keller, J.; Bliesner, R. D. Sprinkle and trickle irrigation. New York: Van Nostrand Reinhold, 1990. 652p. https://doi.org/10.1007/9781-4757-1425-8

Li, M.; Liu, Y.; Yan, H.; Sui, R. Effects of irrigation amount on alfalfa yield and quality with a center-pivot system. Transactions of the American Society of Agricultural and Biological Engineers, v.60, p.1633-1644, 2017. https://doi.org/10.13031/trans.12239

Li, Y.; Bai, G.; Yan, H. Development and validation of a modified model to simulate the sprinkler water distribution. Computers and Electronics in Agriculture, v.111, p.38-47, 2015. https://doi. org/10.1016/j.compag.2014.12.003 
Li, Y.; Yan, H.; Li, M.; Wang, Z. Sprinkler package modification for a center pivot irrigation system in an alfalfa field. International Agriculture Engineering Journal, v.25, p.121-132, 2016.

Monteiro, J.; Tarjuelo, J. M.; Carrión, P. SIRIAS: A simulation model for sprinkler irrigation - II. Calibration and validation of the model. Irrigation Science, v.20, p.85-98, 2001. https://doi. org/10.1007/s002710000032

Oliveira, H. F. E. de; Colombo, A.; Faria, L. C.; Beskow, S.; Prado, G. do. SAI: Modelo para simulação da irrigação por aspersão Calibração e validação. Revista Brasileira de Engenharia Agrícola e Ambiental, v.17, p.253-260, 2013. https://doi.org/10.1590/ S1415-43662013000300002

Prado, G. do; Colombo, A. Caracterização técnica do aspersor PLONARL300. Irriga, v.10, p.53-63, 2005. https://doi.org/10.15809/ irriga.2005v10n1p53-63

Prado, G. do; Colombo, A.; Barreto, A. C.; Matos, F. G. de; Ferreira Júnior, J. J. Uniformidade de aplicação de água pelo aspersor PLONA-RL250 em sistemas estacionários de irrigação. Irriga, v.13, p.220-234, 2008. https://doi.org/10.15809/ irriga.2008v13n2p220-234

Prado, G. do; Colombo, A.; Biagioni, P. F. Análise da uniformidade de aplicação de água pelo aspersor PLONA-RL400 em sistemas autopropelidos de irrigação. Engenharia Agrícola, v.27, p.346-353, 2007. https://doi.org/10.1590/S0100-69162007000300003
Prado, G. do; Faria, L. C.; Oliveira, H. F. E. de; Colombo, A. Efeito do ângulo do jato nas características técnicas de um canhão hidráulico. Revista Brasileira de Engenharia Agrícola e Ambiental, v.17, p.689697, 2013. https://doi.org/10.1590/S1415-43662013000700001

Rolland, L. Mechanized sprinkler irrigation. Roma: Food and Agriculture Organization of the United Nations, 1982. 409p. Irrigation and Drainage, Paper 35

Solomon, K.; Kodoma, M. Center-pivot end sprinkler pattern analysis and selection. Transactions of the American Society of Agricultural Engineers, v.21, p.706-712, 1978. https://doi. org/10.13031/2013.35372

Waller, P.; Yitayew, M. Center-pivot irrigation systems. In: Waller, P.; Yitayew, M. (eds.). Irrigation and drainage engineering. Bern: Springer International Publishing, 2016. Chap.12, p.209-228. https://doi.org/10.1007/978-3-319-05699-9_12

Willmott, C. J.; Ackleson, S. G.; Davis, R. E.; Feddema, J. J.; Klink, K. M.; Legates, D. R.; O'Donnell, J.; Rowe, C. M. Statistics for the evaluation and comparison of models. Journal of Geophysical Research, v.90, p.8995-9005, 1985. https://doi.org/10.1029/ JC090iC05p08995

Zolin, C. A.; Coelho, R. D.; Paulino, J.; Folegatti, M. V. Economic viability of retrofitting emitters in center-pivot irrigation systems. Engenharia Agrícola, v.32, p.602-608, 2012. https://doi. org/10.1590/S0100-69162012000300019 